\title{
GASTRONOMY TOURISM AND DESTINATION BRANDING: THE STUDY OF MICHELIN-STARRED RESTAURANTS IN CROATIA
}

\author{
Matea Hanžek ${ }^{1}$ (i) \\ Gordi Sušić
}

DOI: https://doi.org/10.31410/tmt.2020.211

\begin{abstract}
This paper explores the role of Michelin-starred restaurants and their chefs as change-makers and advocates of successful gastronomy tourism destination branding in Croatia. In this qualitative research, in-depth surveys were conducted with all of the seven chefs of Michelin-starred restaurants in Croatia. These restaurants are: Draga di Lovrana, Boškinac, Monte, Pelegrini, LD Restaurant and $360^{\circ}$ located in Zagreb, Lovran, Novalja, Rovinj, Šibenik, Korčula and Dubrovnik. Results of research uncover whether and which are the significant forms of activities that Croatian Michelin-starred restaurants implement in order to enhance destination attractiveness and by that influence placing Croatia on the world gastronomy map, creating stronger gastronomy destination brands.
\end{abstract}

Keywords: Gastronomy, Tourism, Destination branding, Food, Luxury gastronomy, Michelin-starred restaurants, Croatia, Gastronomy tourism.

\section{INTRODUCTION}

Good is often one of the most important elements in discovering cultures and attracting gastronomy tourists to destinations (Batat, 2020). Gastronomy tourism includes eating and drinking experiences that occur during visiting destinations. Therefore, tourists expect to experience diverse food cultures through trying different specialties that are known to be a part of the culture they visited. There is much scientific literature that has focused on the demand side of gastronomy tourism (Henderson, 2009), exploring the way that tourists experience cultures through food experiences (Ellis, Park, Kim, \& Yeoman, 2018). What they explore is the connection between food experience and tourism destination attractiveness through feelings and memories tourists take home with them (Henderson, 2009). Despite revealing an important knowledge of positive food experiences enhancing destination attractiveness, these studies do not look at the supply side of gastronomy tourism. They lack knowledge about the role of restaurants and chefs in building positive tourism destination brands through luxury gastronomy tourism. Hence, gastronomy tourism, as being an integral part of the food and cultural tourism activities, is a growing market attracting not only the luxury niche but many different segments of tourists (Batat, 2020). Only few scientific articles have shown the importance of luxury gastronomy tourism as being an important area of research (Batat, 2020; Barrere et al., 2014) implying that this area of research can inform other tourism scholars of different strategies of marketing activities that can be used in promoting destinations. Their research is however mostly referenced to France and French gastronomy tourism. In the context of gastronomy tourism research in Croatia, a little attention has been given, mostly focusing on the quality of food produced in Croatia and its potential for Croatian tourism (Šimundić \& Krešić, 2002); health benefits of Croatian national cuisine (Šimundić, 2000); and reinventing of gastronomy tourism in Croatia (Milotić et al., 2002; Fox, 2007); however, none of these look at the supply side, i.e. an insider's perspectives from the chefs of Michelin-starred restaurants in Croatia.

$1 \quad$ Zagreb School of Economics and Management (ZSEM), Vukasovićeva ulica 1, Zagreb, Croatia

2 Zagreb School of Economics and Management (ZSEM), Vukasovićeva ulica 1, Zagreb, Croatia 
The luxury gastronomy tourism trends resulted in the growth of demand for visiting destinations that are in the Michelin guide. Michelin guide restaurants have, according to research by Barrere et al. (2009), increased tourist frequentation by $25 \%$ with a number of more than 15000 restaurants in Michelin guide, in more than 30 countries, out of which 2673 are Michelin starred restaurants (Michelin Guide, 2021). Therefore, Michelin guide can be considered as a strong competitive advantage for destinations with their restaurants on the list. Despite the relationships between gastronomy and tourism have been acknowledged in the anthropology of food and social sciences literature for many years (Bessiere , 1998), very few of them explored gastronomy from the tourism and hospitality management side. Therefore, this research aims at filling this gap which could be used in destination branding strategies to enhance visits to both Michelin guide restaurants and consequently positively affect building stronger destination brands. Finally, this research aims at exploring (1) the relationships between luxury gastronomy and tourism; and (2) to understand the role that Michelin-starred restaurants and their chefs have in enhancing tourism destination branding through attracting both domestic and international tourists.

The paper is divided into five parts. It starts with a literature review that helps the reader better understand what is meant by gastronomy tourism, luxury gastronomy and its connection to luxury tourism destination branding. The review section also emphasizes the importance of the holistic approach to gastronomy tourism, Croatia's place in the Michelin-restaurant world, and the value of its gastronomy tourism. Secondly, the paper focuses on research methodology and provides a rationale for a survey used on a sample of all the seven chefs of Michelin-starred restaurants in Croatia. The research results are outlined in the third part and are presented through the common themes that emerged during the research. Conclusion and future potential research directions are two final parts of the paper.

\section{LITERATURE REVIEW}

\subsection{Gastronomy Tourism}

The concept of gastronomy tourism incorporates an integrated process from food production, food preparation and finally food consumption (Long, 2004). The concept of gastronomy tourism has a lot of different definitions but is mostly defined as the journey for authentic, distinctive, unique and enduring experiences in the destinations (Ellis et al., 2018; Henderson, 2009). This process additionally includes tourists ' discovering the history and culture of a destination through food heritage and traditions (Long, 2004). For example, Hall and Mitchell (2005) defined culinary tourism as visiting primary or secondary food producers, food festivals, restaurants, and specific locations for which food tasting and experiencing the food of attributes of creating region are the primary reason for visiting destination. Culinary tourism, in addition to experiencing food in destination, incorporates learning about new cultures of destinations that tourists visit (Hall, 2006). More so, research on Croatian wine tourism showed that gastronomy tourists seek to find a combination of wine tasting of the region to be connected with gastronomy experience of the same region (Hanžek \& Sušić, 2019).

According to Hall and Mitchell (2005) there are three segments of gastronomy tourists. Firstly, gourmet tourists whose primary purpose of traveling to destination is visiting a limited number of internationally renowned restaurants. Secondly, culinary tourists focus on authenticity and embeddedness in the local culture and plan their visit to the destination based both on cultural 
and culinary experiences. Finally, occasional culinary tourists who do not visit destinations primary because of gastronomy, however, can be involved in culinary activities. All these segments are important for destinations and knowing the values and purpose of travel for each of the segments helps destinations to create unique culinary products and experiences that each segment will seek to find in the destination. Despite the evident strong connection between the destinations and local food culture and promotion, this still stays an under researched field of study, especially in the context of luxury gastronomy tourism, as well as in the context of Croatian tourism destination brand.

\subsection{Luxury Gastronomy}

Luxury consumption is not only connected to products and brands but is directly connected to extraordinary lived experiences. Batat (2020:3) defines it as a search for emotions, pleasure, consideration, uniqueness, and greatest services through lived experiences. More so, luxury gastronomy such as visiting and experiencing Michelin-starred restaurants presents a highly exceptional domain where "experience is a central component of the offer" (Batat, 2019:24). Therefore, luxury gastronomy is an interesting field for luxury tourism and its stakeholders as promotion of luxury gastronomy can be interesting for destination branding. Gastronomy comes from the Greek word gastronomia which means "the art of the good food" (Batat and De Kerviler, 2020). Gastronomy has been conceptualized for the first time in 1825 by the French gastronomist Brillat-Savarin who defined it as "systematic understanding of all that relates to individuals, as they eat" (Batat, 2020). More so, gastronomy aims to preserve humankind through the finest likely food (Batat et al., 2019). Another definition of gastronomy has been offered by Batat (2020:3) as a continuous search for the highest quality, a hedonistic desire, a pleasure, a set of knowledge and culture. Therefore, gastronomy incorporates the cultural heritage of a country and should constitute one's heritage regardless to the social position (Staiff \& Bushell, 2013). Unfortunately, only few countries have pushed gastronomy on the global map. For example, French gastronomy and chefs are perceived as the art makers with food and are the benchmark for the art of food and fine dining. Similar to any luxury product where the designer is the most important part for the branding, in the gastronomy world it is a chef with a Michelin stars.

Chefs need to have a story to tell through their art in cuisine in order to be able to immerse visitors with unique dining experiences. Batat (2020:3) argues that luxury gastronomy gives a competitive advantage to destinations as it helps to retain and attracting local and international visitors making them want to re-visit the destination to live a unique and highly creative food experience delivered by the renowned Michelin-starred chef. With regards to existing research, most focus on tourism and gastronomy without being aware of segmentation, meaning they are not looking at different ways that each segment brings to destination branding strategies. Surely, luxury gastronomy plays an important role in attracting tourists to visit destinations. Mostly, it is done through TV culinary shows that feature Michelin-starred chefs, as well as through different magazines. Finally, what gastronomy tourists seek is a unique living experience through exploring the Michelin-starred chefs' creative cuisine (Batat, 2020).

\subsection{Gastronomy Tourism and Destination Branding}

As already mentioned in the paragraphs above, gastronomy is becoming increasingly important and central to experiencing tourism destinations. With the rise of the experience economy (Pine \& Gilmore, 2011) food has become one of the central elements for successful destination 
branding strategies. Therefore, food has transformed its role from being fundamental support to tourism to becoming an essential reason to visit many destinations. Food is important for tourism destination branding because it gives a sense of place allowing tourists to directly emerge with local culture through "tasting" the destination. It is doing through the following ways (Richards, 1996):

1) Gastronomy presents the culture that tourists come into contact with most often during their visit to destinations;

2) Gastronomy provokes a direct bodily confrontation with culture;

3) Eating habits directly show destinations differentiation through time people eat, why people eat, what they eat and who they eat with; and

4) Food is directly connected with the landscape as we can see directly where the food we eat comes from.

Gastronomy, therefore, provides great support for tourism destination branding strategies. Food can thus be used as the main ingredient in destination branding because it covers many important elements of branding. These elements are products (food and beverages); practices (eating and meals); customs and arts of food preparations and eating (gastronomy); all of the four reals of experiences (look, smell, touch, taste); food origins (knowing where ingredients come from); food preparation (the different ways of cooking); forms of serving (slow food, fast food, street food, etc.); and finally the context in which the food has been served and consumed (markets, streets, restaurants, bars). As much as it seems straightforward in implementing these elements into the destination branding strategy it is far more complex as it seems. The research by the OCTA (2014) suggest the existence of ten criteria for developing successful destination and by that compelling local "taste of place" (see figure 1 below).

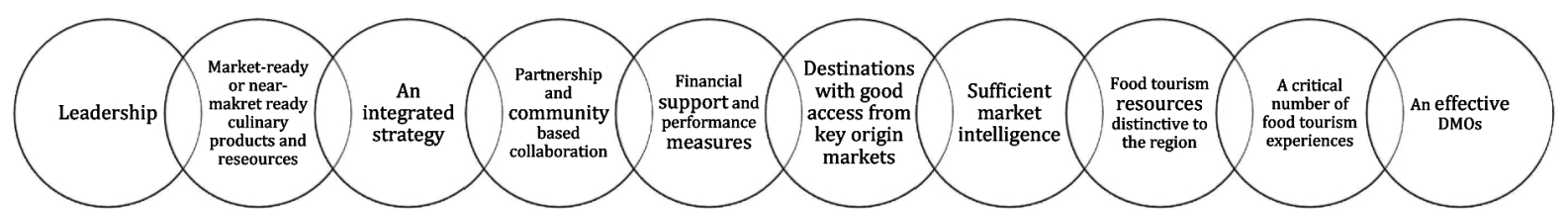

Figure 1. Criteria for developing successful gastronomy destination brand

Source: Adapted from OCTA (2014)

Adding to the above criteria Berg and Sevón (2014) argue that there are three basic functions of gastronomy branding and these are: (1) to support the food industry; (2) to protect and amplify identities and places; and (3) to change the place. Therefore, this research looks at how Croatia is currently implementing gastronomy in destination branding strategy as well as it looks as where Croatia is currently located at the world map of gastronomy tourism by focusing on the Michelin-starred restaurants in Croatia. More so, it looks at their role in developing stronger destination brands.

\subsection{Gastronomy Tourism in Croatia}

In 2019, Croatia achieved record tourist results since its independence. In absolute terms, Croatia's revenues from tourism amounted to EUR $10.5 \mathrm{bn}$ or $19.5 \%$ of its GDP. In terms of physical indicators, the country recorded 17.4 million arrivals of foreign guests and 84.1 million nights spent. These good achievements are not a recent phenomenon. After the global financial crisis, which had only a short-term negative impact on tourist turnover and consumption by foreign tourists in Croatia, tourism revenues on average grew annually by $6.7 \%$ and foreign tourist ar- 
rivals by $7.2 \%$. Compared to the other EU Member States, Croatia's economy relies significantly on the tourism sector, expressed either in relative (GDP) terms, shares in total services exports, gross value added or employment (figures 2-5). Nevertheless, Croatia still has a lot of space to expand its comparative advantage in tourism and to deepen the quality of services offered, notably to higher spending visitors. In this respect, gastronomy plays and will continue to play an important part and role.

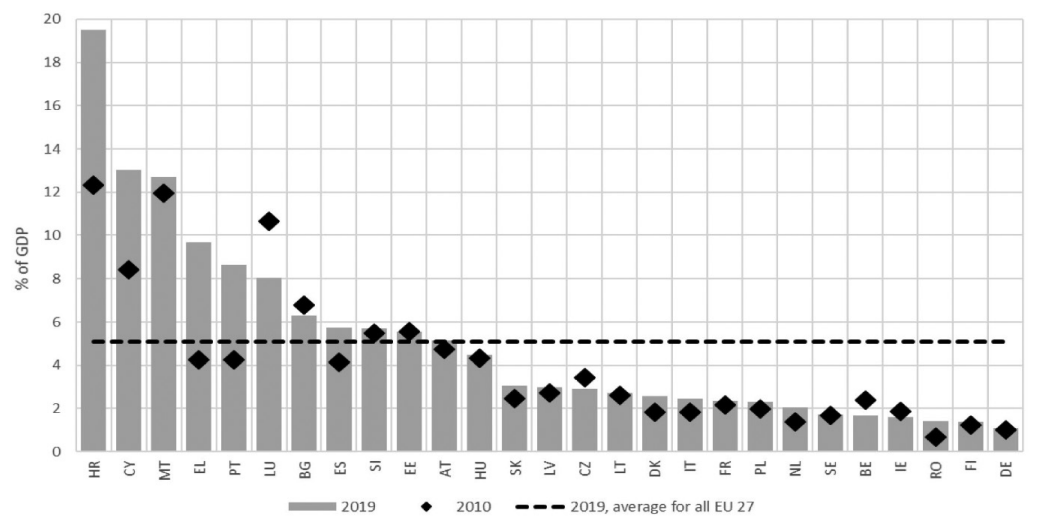

Figure 2. Tourism revenues in Croatia and other EU 27 member states (\% of GDP)

Sources: HNB, Eurostat

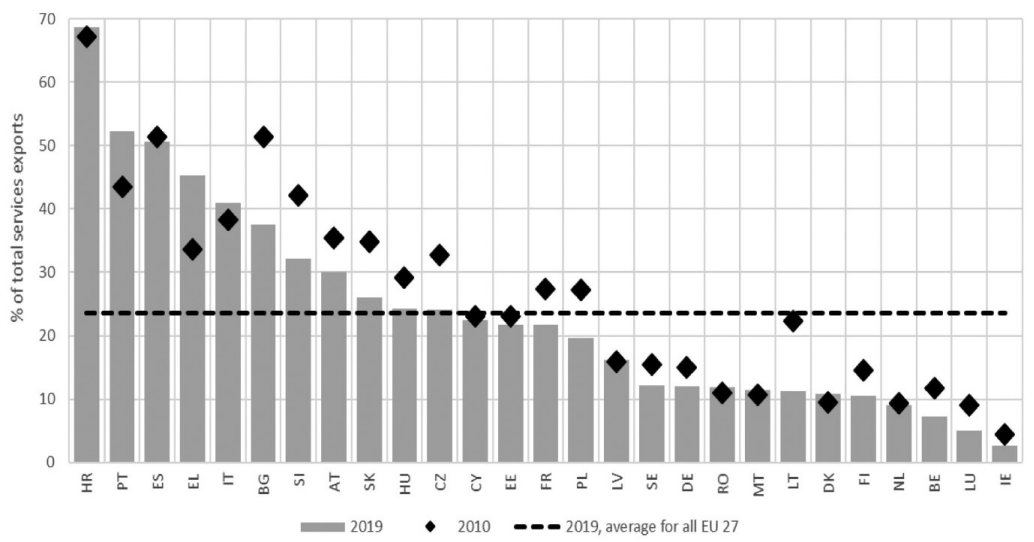

Figure 3. Tourism revenues in Croatia and other EU 27 member states (\% total services export) Sources: HNB, Eurostat

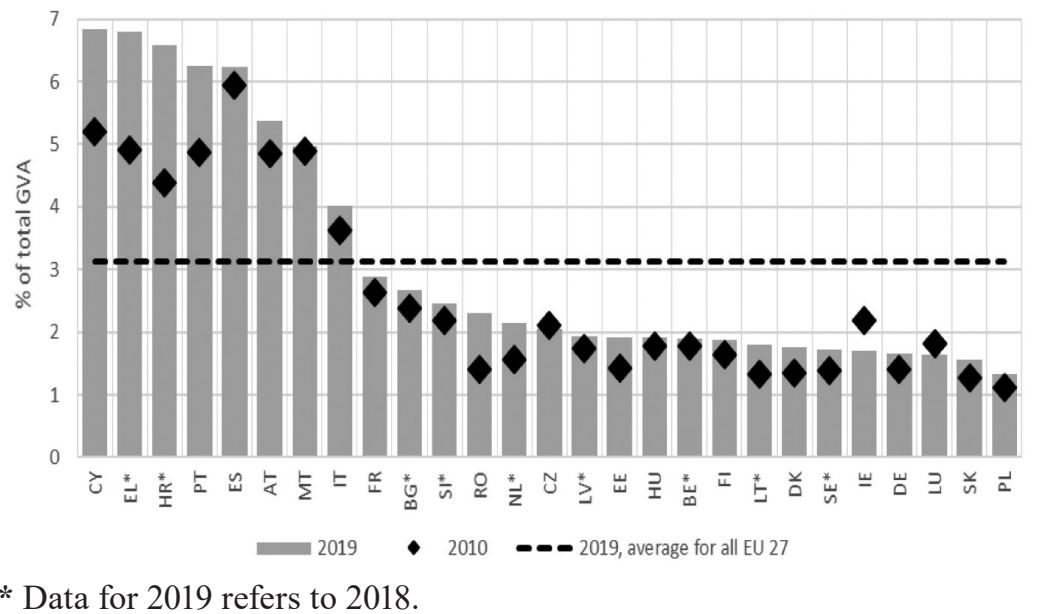

Figure 4. GVA in accommodation and food service activities (\% of total GVA)

Source: Eurostat 




Figure 5. Employment in accommodation and food service activities ( $\%$ of total employment) - labor force survey

Source: Eurostat

Therefore, from the branding point of view, it is one of the rare channels that has a role in creating positive images of Croatia on a global scale. For a long time, Croatia has been basing its destination competitiveness on the sun and sea, i.e. natural resources. This strategy resulted in removing characteristics that differentiate Croatia from other Mediterranean countries and has resulted in problems of high seasonality and low returns on investments (ROI) (Šimić \& Pap, 2016). Nevertheless, the food industry in Croatia both in terms of natural and human resources quality has an existing strong quality foundation that is needed for becoming internationally recognized as a world gastronomy destination. More so, Croatia is both geographically and culturally divided into the three basic regions: (1) Pannonian, (2) Dinaric, and (3) Adriatic, which is also reflected in cuisine differences (Žamper, 2004). Such a variety in a relatively small area can empower the creation of a rich gastronomic offer, through presenting its own gastronomy identity and create an image of Croatia as a high-quality gastronomy destination brand. This research especially focuses on the luxury gastronomy segment.

Unlike French and Italian gastronomy tourism destinations, Croatian destinations do not find their gastronomy offer on local cuisine. Food that is typically being served in Croatian tourism destinations restaurants is still pizza, pasta, ćevapi, Wiener schnitzel, all referenced to Italian, Bosnian and Austrian national cuisines. This does not mean that Croatia lacks quality restaurants and chefs upon where it can brand itself as a luxury gastronomy destination. On the contrary, Croatia has altogether 70 restaurants listed in the Michelin Guide. 53 of them are on the Plate Michelin list; 10 on the Bib Gourmand list and 7 are on the 1* Michelin list (Michelin Guide, 2020). These restaurants with their offer, design and cuisine can compete with the best restaurants in the world. This research, therefore, concentrates on these seven restaurants in Croatia that have 1 Michelin star to examine how they interpret Croatia's rich gastronomic heritage and analyses their role in placing Croatia on the world gastronomy map.

\section{RESEARCH METHODOLOGY AND METHOD}

Given the exploratory nature of the research question, this study is grounded in social constructivism applying a qualitative research approach (Denzin \& Lincoln, 2018). This methodology is suitable for the research aims and objectives as the field of luxury gastronomy tourism is emergent due to a noticeable lack of prior studies on the role of such gastronomy in promoting tourism destinations (Batat, 2020). Figure 6 below shows the methodological approach that researchers followed while conducting this study. 


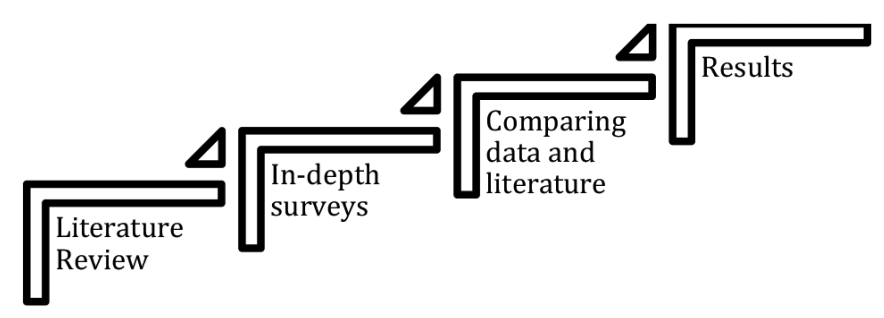

Figure 6. Qualitative method approach for data collection

Source: Authors

In order to examine the role of luxury gastronomic restaurants in tourism destination branding and promotion, in-depth surveys were conducted with all of the seven Michelin-starred restaurants in Croatia. The aim was to develop an understanding of how Michelin-starred restaurants can become promoters and building bricks of gastronomy tourism of a destination. This research additionally aimed at understanding the luxury restaurants' perspective shaped by both socio-cultural and economic environments in which they operate. In doing so, qualitative research has been undertaken. According to the Michelin Guide (2020), there are seven Michelin-starred restaurants in Croatia. In order to generate sufficiently strong results, the sample included all of the seven Michelin-starred restaurants. Table 1 below provides a brief description of the luxury gastronomic restaurants explored in this research, whereas figure 7 shows their location on the map.

Table 1. Description of the Croatian Michelin-starred restaurants in 2020

\begin{tabular}{|l|l|l|l|}
\hline Restaurant & Michelin stars & Chef & City \\
\hline Noel & $1^{*}$ & Goran Kočǐs & Zagreb \\
\hline Draga di Lovrana & $1^{*}$ & Deni Srdoč & Lovran \\
\hline Boškinac & $1^{*}$ & Matija Bregeš & Novalja \\
\hline Monte & $1^{*}$ & Danijel Đekić & Rovinj \\
\hline Pelegrini & $1^{*}$ & Rudolf Štefan & Šibenik \\
\hline LD Restaurant & $1^{*}$ & Marko Gajski & Korčula \\
\hline $360^{\circ}$ & $1^{*}$ & Marijo Curić & Dubrovnik \\
\hline
\end{tabular}

Source: Adapted from Michelin Guide (2020)



Figure 7. Geographical location of Croatian Michelin-starred restaurants in 2020

Source: Adapted from Michelin Guide (2020) 
After a thorough literature review, in-depth surveys with Michelin-starred chefs were conducted. The survey was divided into four sections, each focusing on a certain topic relevant to the research. These topics were as follows: knowledge about the chefs, knowledge about the restaurant, restaurant and destination promotion, concluding questions. These primary sections were further sub-divided, allowing for the collection of more detailed and categorized data that were based on the themes around tourism, tourism destination branding, economic development, local producers and food festivals in relation to the luxury gastronomy tourism sector that they are all a part of. Each section opened with a more general question and then was followed with a certain number of sub-questions addressing the general one in more detail.

The in-depth survey questions are outlined in the Table 2 below.

Table 2. Questionnaire sections and the rationale of their inclusion in the research

\begin{tabular}{|c|c|}
\hline Survey Sections & Questions \\
\hline Introduction & $\begin{array}{ll} & \text { Tell us more (few sentences) about you. } \\
\text { - } & \text { What is your career journey? } \\
\text { - } \quad \text { What is your work approach and philosophy? }\end{array}$ \\
\hline $\begin{array}{l}\text { About the } \\
\text { Restaurant }\end{array}$ & $\begin{array}{l}\text { - } \quad \text { Can you define your cuisine? What is unique about it? } \\
\text { - } \quad \text { When did you (together with your team/restaurant) receive the Michelin Star? } \\
\text { - What do you offer in your restaurant? Describe us your signature dish? } \\
\text { - Where does your inspiration come from? } \\
\text { - } \quad \text { How do you design a unique food experience? } \\
\text { - } \quad \text { Are they locals or mostly tourists? }\end{array}$ \\
\hline $\begin{array}{l}\text { Restaurant and } \\
\text { Destination } \\
\text { Promotion }\end{array}$ & $\begin{array}{l}\text { - } \quad \text { Where do you see Croatia on the world gastronomy map today? } \\
\text { - } \quad \text { How would you define your relationship with the destination (city/region/country)? } \\
\text { - } \quad \text { Ho you think that your restaurant plays a role in promoting the destination and } \\
\text { attracting tourists? } \\
\text { - How would you describe your connection to gastronomy tourism? } \\
\text { - How do customers and tourists perceive your activities? } \\
\text { promoting gastronomy tourism activities? }\end{array}$ \\
\hline $\begin{array}{l}\text { Concluding } \\
\text { Questions }\end{array}$ & $\begin{array}{l}\text { - What do you think the next steps in luxury gastronomy tourism will be? } \\
\text { - What are the key challenges? } \\
\text { - How could local, regional and national tourism boards help you in achieving your } \\
\text { - Wuture goals? } \\
\text { Who would be other stakeholders that you see as an important partner? } \\
\text { next } 10 \text { years? }\end{array}$ \\
\hline
\end{tabular}

Source: Authors

The survey questionnaire was sent out via e-mail to all of the seven Michelin-star chefs. While analyzing data, each of the seven surveys were looked independently, and then compared and analyzed in order to create meaningful and properly organized data. The analysis of surveys revealed coding categories associated with the role of the Michelin-starred restaurants in promoting gastronomy tourism and the role it has in destination branding. This data was then used to compare the results of the survey taking into account the previously conducted literature review. Finally, comprehensive conclusions were made, presented in research results and discussion that follows. 


\section{RESEARCH RESULTS AND DISCUSSION}

The findings of the research confirmed the existence of a strong relationship between luxury gastronomy tourism and Michelin-starred restaurants. More so, research surveys revealed several common themes that often mirrored the literature review and secondary data collection with regards to the importance and the role that Michelin-starred restaurants have in creating stronger gastronomy tourism destination brands. Research results are divided into the four main themes: (1) four realms of experiences in Michelin-starred restaurants; (2) experiences inside Michelin-starred restaurant becoming experiences in the destination; (3) Michelin-starred restaurants and their relationship with tourism stakeholders; and (4) promoting destination through promoting Michelin-starred restaurants. Each is discussed separately in the text that follows.

\subsection{The four realms of experiences in Michelin-starred restaurants in Croatia}

Findings revealed the use of experience economy in creating experiences in each of the seven Michelin-starred restaurants in Croatia. In order to create an exceptional gastronomy experience, restaurants combine education, entertainment, aesthetics and escapism in a variety of ways that makes a distinctive difference between food tourism and luxury tourism products.

\section{Education}

As many sociocultural factors are directly connected to gastronomy, this research has shown that Michelin-starred restaurants play an important role in promoting local food culture and heritage and at the same time educate guests about it. They do so through attracting tourists with their offer that is always based on the local culture and heritage, emphasizing culinary traditions of the local terroir ${ }^{3}$. What chefs further suggested is that tourists that visit their restaurants do not come there only to eat, they come to educate themselves and to discover the local culture. As one of the chefs said:

"My guests talk to me about the heritage of food I serve. They want to know entire process from where the food comes from to why it was served the way it was. I like to answer such questions because I feel like my job is to educate people about my culture and heritage from media of food. This kind of guests travel around the world and compare culture through gastronomy experiences. You can learn a lot this way, and it is entertaining, it is education through pleasure".

More so, in 2013 Mediterranean Diet ${ }^{4}$, specific for Mediterranean countries, was inscribed on the UNESCO Representative List of the Intangible Cultural Heritage of Humanity, where Croatian gastronomy can base its gastronomy offer as a lot of tourists seek to understand and learn secrets of the Mediterranean diet (UNESCO, 2013).

3 Terroir presents the complete natural environment in which a particular food and wine is produced, including factors such as the soil, topography, and climate. As Batat and De Kerviler (2019) state, it is a strong connection with the identity of the region/territory associated with.

4 The Mediterranean diet involves a set of skills, knowledge, rituals, symbols and traditions concerning crops, harvesting, fishing, animal husbandry, conservation, processing, cooking, and particularly the sharing and consumption of food. Countries on the list with Mediterranean Diet are Croatia, Cyprus, Spain, Greece, Italy, Morocco and Portugal (UNESCO, 2013). 


\section{Entertainment}

Research revealed that visiting Michelin-starred restaurants produces entertainment for tourists through looking at food, tasting it and matching it to a different kind of wine. As one of the chefs stated:

"It is like an entertainment for our guests. They get entertained through different courses that come to table during their dinner, through design on plate to different tastes of our cuisine".

An entertainment part of the realms of experiences means that each of the Michelin-starred restaurants tries to make an experience that encompasses elements of hedonism, identity, experientialism, and symbolism making altogether a unique luxury gastronomy product (Batat, 2010).

\section{Aesthetics}

The main point of difference between the popular and traditional restaurants and Michelin-starred restaurants in Croatia is an appeal that they leave on individual's perceptions taking into account smell, taste, vision, sound and touch in order to create an exceptional experience (Batat, 2019). As one of the chefs mentioned:

"I use aesthetics as one of the main guidelines while thinking about the dish... Every meal needs to be like art, where each of the guests will experience it on their own way. It is like an art gallery with different exhibits that need to evoke variety of feelings to one that tastes them".

What sets these restaurants apart is the creation of emotions and pleasure while at the same time dishes they eat promote the cultural heritage of the destination, as well as memories that tourists share after their visit.

\section{Escapism}

For Michelin-starred restaurants escapism is one of the main ingredients while thinking about offering a unique luxury gastronomy experience. As chefs have agreed, they all focus on the experiential pleasure of food knowing that tourist's basic motif for travel is to escape from everyday life and try something different that they cannot find at home or near home. One of the chefs added:

"You can escape your everyday life through gastronomy, experiencing both aesthetics of our food and restaurant itself. It is all one big experience where you feel different than usual. Going to Michelin-starred restaurant is not an everyday thing. It is rather a special thing; it is an occasional escapism".

Therefore, in order to create a unique experience and to allow tourists to co-create the experience, owners of the luxury restaurants need to recognize different expectations that various tourists might have, operating on a number of different social scales and scopes (Dean et al., 2010). Combining all four realms of experience offers a formula to creating a successful unique luxury gastronomy experience. 


\subsection{Experiences inside Michelin-starred restaurant become experiences in destination}

Findings of the research showed that there is a strong connection between the luxury gastronomy tourism destination and Michelin-starred restaurants. All surveyed Michelin-starred chefs state that experiences that tourists gain are pleasure and food well-being and that as such the offer that they have becomes destination offer. What they offer is the highest quality of ingredients, creativity of recipes, the aesthetics of dishes and through combining all four realms of experience they stage unique luxury gastronomy experience that is attractive for domestic and international tourists that makes luxury offer in the destination stronger. What tourists seek for while experiencing luxury gastronomy is not only food tasting, but interaction with local producers and chefs in restaurants. One of the chefs mentioned that:

"Tourists in my restaurant wait for me to come out of the kitchen and to have a conversation with me. We talk about Croatia and then about food from Croatia. It is like promoting tourism destination, it's culture and heritage. I like to say that we are terroir promoters".

Another chef said:

"People who experience cuisine in my restaurant often talk about it for example not saying that restaurant had great food, but that Croatia has amazing kitchen".

As discussed in the previous chapter, there is a strong connection between Michelin-starred restaurants and destination. Unfortunately, research has shown that in the case of Croatia, Michelin-starred chefs are more aware of it then Croatian tourism boards and other important stakeholders. This will be in more detail be discussed in the discussion that follows.

\subsection{Michelin-starred restaurants and their relationship with tourism stakeholders}

Relationship with stakeholders in destination is important both for Michelin-starred restaurants as well for destination itself. Surveyed chefs outlined the relationships they argue about are the most important for them, and they are: (1) local farmers, (2) local wine producers, (3) local designers, (4) local hoteliers, (5) local florists, and (6) local ceramists. More so, research on Croatian premium small to medium-sized wine producers showed strong dependence of wine makers on luxury tourism segment in Croatia (Hanžek \& Sušić, 2019), which can be seen in the food segment too. This research has shown that $20 \%$ of the Michelin-starred restaurants in Croatia are a part of the small luxury private hotels, while other $80 \%$ argued that they heavily rely on luxury hotels and accommodation that is located around the restaurants. They all agreed that local relationships are something they build their strategy on. All of the seven Michelin-starred restaurants use terroir products in their branding strategies both domestically and internationally because it indicates authenticity, quality, and local culture and heritage. For example, one of the chefs argued:

"My restaurant collaborates with many local businesses. Local family producers are something I rely on daily basis and it is why these relationships have to be strong. What I especially like is the collaboration with young artist who works with ceramics. I love his design for plates and kitchenware that he designs for my restaurant, it makes it even more special. Many tourists ask where these ceramics come from, and they end up ordering it from his website as memorabilia for eating in my restaurant and consequently as memorabilia of their stay in Croatia. I am happy we helped this young artist grow his business". 
Another one added:

"Everything you can find in my restaurants is form island, we find here everything we need, it is then local, traditional, authentic, it is an island identity".

On the other side, research has shown that there is lack of cooperation with tourism boards, as one of the chefs mentioned:

"I feel they really do have that strength to go and build Croatia as a luxury gastronomy destination, but somehow they don't". Another chef added "we would like this relationship with tourism boards to be stronger, they need to place more attention to luxury gastronomy and move away from emphasizing sun and sea, there is so much more to offer".

What luxury gastronomic experiences do is building and emphasizing strong relationships with restaurant and culture of the destination, through collaboration with other stakeholders in the destination together presenting the history and identity of the place. Consequently, strong relationships in the destination helps local family businesses grow and sustain their businesses. Overall, development of luxury gastronomy offer positively effects local businesses to become more creative, it creates new jobs and through keeping it local it gains global reputation. This allows destinations to keep traditional know-how within the territory and preserve it for future generations.

\subsection{Promoting destination through promoting Michelin-starred restaurants}

Research has shown that Michelin-starred restaurants play an important role in building luxury gastronomy destination brands. They are doing so in many different ways. Firstly, chefs are promoters not only of themselves but as well as of restaurants and consequently of destinations. Michelin-starred chefs have a role as gastronomy influencers, they are the restaurant brand creators. One of the chefs said:

"I use social media to promote my restaurant and cuisine. Instagram is my favorite one, there I also communicate with my guests. When I publish some of the shows that I had privilege to be in, it immediately gets a huge impact on visibility, not only of restaurant but destination as well".

As Batat (2010) argues, chefs are more and more becoming celebrities and have a significant media capital through which they can build brand awareness both through on-line and off-line media presence, mostly through their charisma that attracts audiences and then enhances attractiveness of restaurant and consequently destination. The media exposure of chefs and their accessibility on social media is still very weak in Croatia comparing to other successful luxury gastronomy destinations such as France and Italy. There is still a lot of space to build this presence and by that increase visibility of Croatia as a gastronomy destination.

\section{CONCLUSION}

This research has investigated the role of Michelin-starred restaurants and their chefs as a change-makers and advocates of successful gastronomy tourism destination development. It has done so through qualitative research capturing an insider's perspectives from the chefs of all of the seven Michelin-starred restaurants in Croatia. Firstly, research has revealed that Miche- 
lin-starred restaurants have two ways of attracting tourists. They serve as both an individual attraction (more for local visitors) and as a destination attraction, where through their unique cuisine they present the identity and heritage of the destination (attracting international visitors). More so, research has revealed the existence of a strong relationship between luxury gastronomy tourism and Michelin-starred restaurants through several common themes that appeared during the research. Firstly, all seven Michelin-starred restaurants use a different combination of the four realms of experiences (Pine \& Gilmore, 2011) in order to create unique gastronomy experiences. Secondly, through creating these unique experiences for their restaurant, they create experiences that become a destination experience. Thirdly, they build strong relationships with local tourism stakeholders and by that impact on promoting sustainable and authentic tourism product which is contrary to what restaurants are in general connected to. Finally, Michelin-starred restaurants play an important role in building luxury gastronomy destination brands as they are promoting destinations through promoting their cuisine that is always connected to culture, heritage and identity of a destination.

Furthermore, this research has confirmed that Michelin-restaurants, along with their chefs, are change-makers and advocates of successful gastronomy tourism product development focusing on the individual as well as societal well-being of tourists. This research offers a managerial perspective, i.e. supply side of gastronomy tourism destination branding story. By that it contributes to the existing research on this topic which focuses mostly on demand side and neglects understanding motivations and visions that drive Michelin-starred chefs and restaurants to promote luxury gastronomy tourism destination. Michelin-starred restaurants have a strength to act as a tourism destination itself because they operate as ambassadors of local culinary traditions. More so Michelin-starred chefs feel as they need to promote, preserve and value identity and heritage beyond restaurant using their personality, media, prestige and creativity adding this luxury element into gastronomy destination promotion and by that attracting more tourists in luxury segment (Batat, 2020). Tourists visit Michelin-starred restaurants not only to have a local food luxury dining experience, but to consume gastronomy through unique and staged experiences that these restaurants offer through above mentioned different realms of experiences. All Michelin-starred chefs pointed out that they collaborate and work only with local suppliers and buy that positively impact revitalization of areas where restaurants are located.

The results of this study show that despite the enormous efforts that Michelin-starred restaurants and chefs put into creating a unique experience, Croatia as a gastronomy destination is far from the renowned destinations such as France, Spain, Italy and Mexico. These countries see gastronomy tourism as a special segment of the demand and are investing a huge amount of time and effort into gastronomy destination branding. Despite having a great potential for developing gastronomy tourism and specifically luxury gastronomy tourism, Croatia still neglects this segment in destination branding strategies. Should this be included it new branding strategies, it would have a positive effect on overall destination image such as expanding tourist season, increase tourist expenditure, enrich tourist offer, and consequently develop a strong luxury gastronomy destination brand. Finally, examining the role that luxury gastronomy has in developing stronger destination brands brings an important contribution in giving an insight as to how more adequately approach destination branding through gastronomy, and how to implement these into more effective marketing strategies in the future. 


\section{FUTURE RESEARCH DIRECTIONS}

Research based on a larger sample of Michelin-guide restaurants would be of value added, as this research examined only Croatian Michelin-starred restaurants. Also, as this research focused on the supply side of the gastronomy tourism market (Michelin-starred restaurant chefs), this research should be extended to the demand side of the luxury gastronomy tourism market (Michelin-starred restaurant guests) in Croatia. Also, this research revealed an interesting fact that $20 \%$ of the Michelin-starred restaurants are a part of the small luxury hotels in Croatia, and this could also be further researched as a business model. More so, future research projects could attempt to highlight differences between Croatian and similar gastronomy tourism destinations in other parts of the world.

\section{ACKNOWLEDGEMENT}

The authors would like to sincerely thank all the participants in this research for their willingness, time and effort in providing necessary data that enabled this project.

\section{REFERENCES}

Batat, W. (2019). Food and experiental marketing: Pleasure, wellbeing and consumption. London, England: Routledge.

Batat, W., \& De Kerviler, G. (2020). How can the art of living (art de vivre) make the French luxury industry unique and competitive? Marche\&Organisations, 17-34.

Batat, W., Peter, P. C., Moscato, E. M., Castro, I. A., Chan, S., Chungai, S., \& Muldrow, A. (2019). The experiental pleasure of food: A Savoring journey to food well-being. Journal of Business Research, 392-399.

Batat, W. (2020). The role of luxury gastronomy in culinary tourism: An ethnographic study of Michelin-Starred restaurants in France. Int J Tourism Res., 1-14.

Berg, P. O., \& Sevón, G. (2014). Food-branding places - A sensory perspective. Place Branding and Public Diplomacy, 289-304.

Bessiere, J. (1998). Local development and heritage: Traditional food and cuisine as tourist attractions in rural areas. Sociologia Ruralis, 38(1), 21-34.

Dean, C., Donnellan, C., \& Pratt, A. C. (2010). Tate Modern: Pushing the limits of regeneration. London, UK: Tate Modern.

Denzin, N. K., \& Lincoln, Y. S. (2018). The SAGE Handbook of Qualitative Research. London: SAGE.

Ellis, A., Park, E., Kim, S., \& Yeoman, I. (2018). Progress in tourism management. What is food tourism? Tourism Management (68), 250-263.

Fox, R. (2007). Reinventing the gastronomic identity of Croatian tourist destinations. Hospitality Management, 546-559.

Hall, M. C., \& Mitchell, R. (2001). Wine and food tourism. In N. Douglas \& R. Derrett (Eds.). Special interest tourism, 307-325.

Hall, M. C. (2006). Culinary tourism and regional development: From slow food to slow tourism. Tourism Review International, 9(4), 303-305.

Hanžek, M., \& Sušić, G. (2019). Croatian wine tourism from the winery perspective: The case of the Grand Cro. 4th International Thematic Monograph: Modern management tools and economy of tourism sector in present era, 669-685.

Henderson, J. (2009). Food tourism reviewed. British Food Journal, 4(111), 317-326. 
Long, L. (2004). Culinary tourism. Lexington, KY: The University Press of Kentucky.

Milotić, A., Knaus, K., \& Oplanić, M. (2002). The adjustments of agriculture of coastal areas to actual trends of tourist demand. Continental Economical Resources in the Function of Development of Croatian Tourism. Osijek.

OCTA. (2014). Rise of food tourism trend report.

Pine, B., \& Gilmore, J. (2011). The Experience Economy. Boston, Mass: Harvard Business Review Press.

Richards, G. (1996). The scope of significance of cultural tourism. In G. Richards (Ed.). Cultural tourism in Europe, 19-45.

Staiff, R., \& Bushell, R. (2013). The Rhetoric of Lao/French fusion: Beyond the representation of the Western tourist experience of cuisine in the world Heritage city of Luang Prabang, Laos. Journal of Heritage Tourism, 133-144.

Šimić, M. L., \& Pap, A. (2016). Can food be competitive advantage of Croatian tourism? Econviews, 9-20.

Šimundić, B., \& Krešić, G. (2002). The nutritional valorization of food originating from the continental part of Croatia. Continental Economical Resources in the Function of the Development of Croatian Tourism. Osijek.

Šimundić, B. (2000). Gastronomy in the function of a higher quality of tourist offer. Management in the function of Increasing Tourism Consumption. Opatija.

UNESCO. (2013). Mediterranean diet. From Intangible Cultural Heritage: https://ich.unesco. org/en/RL/mediterranean-diet-00884

Žamper, A. (2004). Kulinarstvo - dio kulture življenja i duhovne baštine u hrvatskoj turističkoj ponudi. Naše more, 51, 227-238. 
